\title{
METODE PERMAINAN BINGO MATEMATIK PADA MATERI OPERASI HITUNG PECAHAN TERHADAP HASIL BELAJAR SISWA KELAS IV
}

\author{
Hery Setiyawan \\ Universitas Wijaya Kusuma Surabaya \\ Hery_deathschyte@yahoo.co.id
}

\begin{abstract}
Abstrak
Penelitian ini bermaksud mengembangkan dan mengimplementasikan permainan bingo matematik untuk meningkatkan keterampilan berhitung operasi pecahan siswa SD. Selain itu penelitian ini akan mendeskripsikan hasil belajar, aktivitas belajar respon siswa dalam pembelajaran matematika dengan menggunakan permainan bingo matematik.

Metode yang digunakan dalam penelitian ini adalah metode permainan bingo matematik dengan subjek dalam penelitian ini adalah siswa kelas 4 SDN Pakis V Surabaya. Hasil yang didapat dari penelitian ini berupa data aktivitas siswa yang dikumpulkan menggunakan lembar pengamatan aktivitas siswa yang menunjukkan bahwa siswa aktif dalam mengikuti pembelajaran. Data respon siswa yang dikumpulkan melalui angket terhadap pembelajaran dengan menggunakan metode permainan bingo matematik adalah positif. Data hasil belajar siswa menggunakan tes hasil belajar yang menentukan ketuntasan belajar baik individu maupun klasikal

Aktivitas rata-rata peserta didik aktif lebih besar dari rata-rata aktivitas peserta didik pasif $(66,44 \%>52,62 \%)$, respon yang ditangkap oleh siswa kelas IV SDN Pakis 5 Surabaya selama proses pembelajaran menggunakan metode permainan bingo matematik adalah positif dan memiliki minat dalam mengikuti pembelajaran. Hasil perolehan belajar siswa kelas IV SDN Pakis 5 Surabaya selama proses pembelajaran menggunakan metode permainan bingo matematik adalah sebesar $89,18 \%$ sehingga secara klasikal dapat dinyatakan tuntas.
\end{abstract}

Kata kunci: Operasi hitung pecahan, metode permainan bingo matematik, hasil belajar siswa sekolah dasar.

\begin{abstract}
This study intends to develop and implement mathematical bingo games to improve numeracy skills of elementary school students fractional operations. In addition, this study will describe the results of study before, after and learning activities of students in the learning of mathematics using mathematical bingo game.

The method used in this research is the method of mathematical bingo game with the subjects in this study is the 4th grade students of SDN Pakis V Surabaya. The results obtained from this research is a student activity data were collected using observation sheet student activity indicating that the student is active in the following study. Student response data were collected through questionnaires to learning by using mathematical methods bingo game is positive. Data of student learning outcomes using achievement test that determines whether individual mastery learning and classical
\end{abstract}


Activities average active learners greater than average activity passive learners $(66,44 \%>52,62 \%)$, responses were captured by fourth grade students of SDN Pakis 5 Surabaya during the learning process using mathematical methods bingo game is positive and has an interest in participating in learning. The result of the acquisition of the fourth grade students of SDN Pakis 5 Surabaya during the learning process using mathematical methods bingo games amounted to $89.18 \%$, so the classical can be declared complete.

Keywords : Fractional arithmetic operation, bingo games mathematical methods, student learning outcomes junior high school

Sitasi: Setiyawan, H. 2018. Metode Permainan Bingo Matematik pada Materi Operasi Hitung Pecahan Terhadap Hasil Belajar Siswa Kelas IV. Matematika dan Pembelajaran, 6(2), 101-110.

\section{PENDAHULUAN}

Pendidikan matematika di Indonesia saat ini sedang mengalami perubahan paradigma. Terdapat kesadaran yang kuat, terutama dikalangan pengambil kebijakan, untuk memperbaharui pendidikan matematika. Bertujuan agar pembelajaran matematika lebih bermakna bagi siswa dan dapat memberikan bekal kompetensi yang memadai, baik untuk studi lanjut maupun memasuki dunia kerja. Hal ini tak lepas dari adanya masalah utama pada pembelajaran pada pendidikan formal adalah masih rendahnya daya serap siswa. Begitu juga dalam pembelajaran matematika. Berdasarkan studi yang dilakukan PISA (Program for International Student Assesment) (Rahayu, 2012:15-16) tahun 2006 menyatakan bahwa kemampuan siswa di Indonesia dalam matematika memiliki skor ratarata yang rendah. Hal ini bisa jadi disebabkan karena hingga saat ini matematika merupakan salah satu pelajaran yang menjadi momok yang menakutkan bagi beberapa siswa. Asumsi siswa bahwa matematika sulit sudah menjadi hal yang menjadi rumor paling heboh dibandingkan dengan pelajaran lain. Pada kenyataannya matematika tidak sepenuhnya bisa disalahkan karena ada banyak hal lain yang membuat proses pembelajaran matematika kurang maksimal sehingga matematika dianggap sulit. Beberapa hal tersebut diantaranya kurangnya latihan soal serta pemaksimalan penggunaan berbagai media pembelajaran dalam pemenuhan pelajaran siswa.

Proses pembelajaran matematika di kelas hampir selalu dilaksanakan secara konvensional dengan urutan sajian: (1) diajarkan teori/definisi/teorema melalui pemberitahuan, (2) diberikan dan dibahas contoh-contoh, kemudian (3) diberikan soal latihan. Akibatnya sampai saat ini kualitas pembelajaran di Indonesia masih rendah. Hal 
lain yang menjadi penyebab kesulitan belajar matematika adalah bahwa pada umumnya matematika disajikan sebagai ilmu yang bersifat abstrak, karena matematika melibatkan hal-hal yang abstrak. Hal ini bertentangan dengan kondisi perkembangan siswa usia SD yang masih berada pada tahap operasi konkret. Seperti yang dikemukakan oleh Jean Piaget bahwa anak usia 7 sampai 11 tahun berada pada tahap operasional konkret. Untuk dapat memahami dan menyukai matematika yang bersifat abstrak, maka proses pembelajaran matematika khususnya materi pokok konsep operasi hitung sejatinya disampaikan secara bermakna (meaningful) dan menyenangkan, serta harus mampu menunjukkan manfaat matematika dalam memecahkan berbagai masalah dalam kehidupan (applicability) (Sabandar dalam Rahayu, 2012:3).

Pembelajaran matematika di kelas pada umumnya lebih mengutamakan pada penyampaian informasi bukan penekanan proses pembelajaran. Pembelajaran seperti itu kemudian akan melahirkan model pembelajaran pasif dan tidak demokratis, karena peran inti di tangan guru dan bahkan guru seringkali bersikap otoriter. Menyikapi hal demikian, seorang guru seharusnya dapat melakukan tindakan alternatif yang berguna untuk meningkatkan aktivitas siswa dalam menerima pembelajaran matematika. Sebaiknya guru berupaya menciptakan proses pembelajaran yang terpusat pada siswa. Dengan kata lain, guru dapat menerapkan strategi pembelajaran yang memandang siswa sebagai subyek belajar yang dinamis, sedangkan guru hanya bertindak sebagai fasilitator. Selain itu, selama proses pembelajaran berlangsung, guru juga hendaknya mampu menciptakan suasana belajar yang menyenangkan sehingga terjadi interaksi antara guru dan siswa. Salah satu strategi yang dianggap tepat untuk memecahkan masalah tersebut adalah dengan penerapan pembelajaran melalui metode permainan.

Dengan menerapkan metode permainan diharapkan siswa menjadi aktif berpartisipasi, tidak hanya sebagian siswa tapi semua siswa yang hadir pembelajaran. Selain itu diharapkan agar komunikasi siswa dengan siswa lain dan guru dapat terjalin dengan baik sehingga pesan yang disampaikan guru sama dengan pesan yang disampaikan siswa. Ada beberapa jenis metode permainan, salah satunya adalah metode permainan bingo. Permainan yang mengedepankan unsur-unsur menyenangkan dan luar biasa dalam pemerolehan informasi pembelajaran matematika. Penelitian ini mendeskripsikan peranan permainan bingo matematik sebagai konteks untuk membantu siswa kelas SD memahami konsep operasi hitung perkalian, serta proses belajar siswa yang berkembang dari aktivitas bermain ke aktivitas formal yang bermakna dan menyenangkan. Permainan ini berupa tabel bernomor, dimana siswa dapat menyelesaikan 
soal dengan benar dalam deretan secara horizontal, vertikal, maupun diagonal, maka akan mendapatkan poin yang akan berpengaruh terhadap nilai kelompoknya. Dengan bermain, siswa lebih mudah dalam belajar dan termotivasi yang pada akhirnya dapat meingkatkan kemampuan dan aktivitas siswa. Selain itu dengan metode ini, diharapkan proses pembelajaran dapat mewadahi siswa untuk bekerja sama, toleransi, saling menghargai, mampu mengendalikan emosi, berkomunikasi serta bersifat kreatif dalam pembelajaran sehingga lebih mudah menguasai materi pembelajaran matematika.

Sesuai dengan uraian yang telah dikemukakan di atas, maka penelitian ini bertujuan mendeskripsikan bagaimana aktivitas siswa, respon dan hasil belajar siswa pada mata pelajaran matematika materioperasi hitung pecahan dengan metode permainan bingo matematik di kelas 4 SDN Pakis 5 Surabaya.

Menurut Drs.H Abu Ahmad dkk (2005:52) metode adalah suatu pengetahuan tentang cara - cara mengajar yang dipergunakan oleh seorang guru atau instruktur. Sedangkan menurut kamus besar bahasa Indonesia metode adalah "cara kerja yang bersistem untuk memudahkan pelaksanaan suatu kegiatan guna mencapai tujuan yang ditetapkan.Menurut Djamarah (2006:82-84), metode memiliki kedudukan:

1. Sebagai alat motivasi ekstrinsik dalam kegiatan belajar mengajar (KBM);

2. Menyiasati Perbedaan Individual Anak Didik

3. Untuk Mencapai Tujuan Pembelajaran.

Makin tepat metode yang digunakan oleh guru dalam mengajar, diharapkan makin efektif dan efisien dalam pencapaian tujuan pembelajaranMenurut Djamarah (2006:8284). Tentunya faktor -faktor lain pun harus diperhatikan juga, seperti; faktor guru, faktor siswa, faktor situasi (lingkungan belajar), media, dan lain-lain. Sedangkan Sudono (2000:1) mengemukakan bahwa "bermain adalah suatu kegiatan yang dilakukan dengan atau tanpa mempergunakan alat yang menghasilkan pengertian atau memberikan informasi, memberi kesenangan maupun mengembangkan imajinasi anak".

Dengan bermain anak bisa mengembangkan potensi yang ada dalam dirinya, anakanak akan lebih senang dan menjadikan si anak lebih aktif. Sebagaimana dikemukakan oleh Mayke (dalam Sudono, 2000:3) " belajar dengan bermain akan memberi kesempatan kepada anak untuk memanipulasi, mengulang-ulang, menemukan sendiri, bereksplorasi serta mempraktekkannya. Menurut Sadiman (2002:79) Permainan dapat dipakai untuk mempraktekkan keterampilan membaca dan berhitung sederhana. Tujuan pemberantasan buta aksara dan buta angka untuk orang dewasa atau pelajaran membaca, menulis 
permulaan serta matematika adalah yang lazim dikaitkan dengan permainan. Dalam proses pembelajaran guru hendaknya memberikan kebebasan kepada setiap anak didiknya untuk mengekspresikan apa yang ada dalam pemikiran mereka. Sebaiknya guru juga memberi kebebasan sesuai dengan sifat alami anak sehingga dalam mengembangkan kreatifitasnya anak tidak merasa takut untuk berbeda dengan gurunya.

Dari penjelasan di atas dapatdisimpulkan bahwa metode permainan yang dimaksud adalah suatu cara yang digunakan dalam melakukan kegiatan untuk menjelaskan konsep abstrak dalam Matematika yang lebih menyenangkan (mencegah ketakutan siswa terhadap pelajaran Matematika) agar siswa lebih paham dan lebih lama mengingatnya.

Permainan bingo merupakan upaya guru untuk memecahkan masalah yang timbul dikelas. Kemampuan siswa untuk memecahkan masalah melalui permainan bingo menunjukkan bahwa siswa itu memiliki kemampuan tinggi, siswa dengan kemampuan sedang, ataupun siswa dengan kemampuan rendah dapat meningkatkan hasil belajarnya. Disamping itu pembelajaran dengan permainan Bingo juga dapat meningkatkan antusias dan keaktifan siswa. Hasil belajar siswa dapat terlihat dari hasil tes sebelum diterapkannya permainan bingo dan setelah diterapkannya permainan bingo (Dinar, 2014:43).

Permainan Bingo diterapkan dalam pembelajaran di sekolah, dengan tujuan kompetensi, sebagai berikut:

1. Meningkatkan kemampuan siswa dalam memecahkan masalah-masalah yangdihadapi siswa dalam kegiatan proses pembelajaran disekolah. Seperti pada mata pelajaran matematika masalah perkalian dan pembagian.

2. Meningkatkan antusias dan keaktifan siswa.

3. Memperkaya vocabulary siswa, khususnya pada mata pelajaran bahasa Inggris.

4. Menciptakan suasana pembelajaran yang aktif, inovatif, kreatif, efektif, dan menyenangkan bagi siswa.

Alat-alat dan bahan yang dibutuhkan dalam permainan matematika ini adalah:

1. 1 buah papan bingo matematik yang terbuat dari kertas karton

2. 1 buah gelas yang cukup besar untuk menampung semua question sticks

3. 1 set post it yang berbeda untuk masing - masing kelompok

Pembelajaran matematika adalah proses interaksi antara guru dan siswa yang melibatkan pengembangan pola berfikir dan mengolah logika pada suatu lingkungan belajar yang sengaja diciptakan oleh guru dengan berbagai metode agar program belajar matematika tumbuh dan berkembang secara optimal dan siswa dapat melakukan kegiatan 
belajar secara efektif dan efisien.Selain interaksi yang baik antara guru dan siswa tersebut, faktor lain yang menentukan keberhasilan pembelajaran matematika adalah bahan ajar yang digunakan dalam proses pembelajaran tersebut.

Tujuan pembelajaran matematika di SD adalah

1. Mempersiapkan siswa agar sanggup menghadapi perubahan keadaan dalam kehidupan melalui latihan bertindak atas dasar pemikiran logis, rasional, kritis, cermat, jujur dan efektif

2. Mempersiapkan siswa agar dapat menggunakan matematika dan pola pikir matematika dalam kehidupan sehari-hari dalam mempelajari berbagai ilmu pengetahuan

3. Menambah dan mengembangkan ketrampilan berhitung dengan bilangan sebagai alat dalam kehidupan sehari-hari

4. Mengembangkan pengetahuan dasar matematika dasar sebagai bekal untuk melanjutkan kependidikan menengah

5. Membentuk sikap logis, kritis, kreatif, cermat dan disiplin. Depdikbud, 1996 (dalam Indaryanti, 2014:126-132)

Siswa Sekolah Dasar (SD) berada pada umur yang berkisar antara usia 7 hingga 12 tahun, pada tahap ini siswa masih berpikir pada fase operasional konkret. Kemampuan yang tampak dalam fase ini adalah kemampuan dalam proses berpikir untuk mengoperasikan kaidah-kaidah logika, meskipun masih terikat dengan objek yang bersifat konkret (Heruman, 2012:1-2). Siswa SD masih terikat dengan objek yang ditangkap dengan pancaindra, sehingga sangat diharapkan dalam pembelajaran matematika yang bersifat abstrak, peserta didik lebih banyak menggunakan media sebagai alat bantu dan penggunaan alat peraga. Karena dengan penggunaan alat peraga dapat memperjelas apa yang disampaikan oleh guru, sehingga siswa lebih cepat memahaminya. Pembelajaran matematika di SD tidak terlepas dari dua hal yaitu hakikat matematika itu sendiri dan hakikat dari anak didik di SD.

Tentunya dalam mengajarkan matematika di Sekolah Dasar tidak semudah denganapa yang kita bayangkan, selain siswa yang pola pikirnya masih pada fase operasional konkret, juga kemampuan siswa juga sangat beragam. Hudojo (2005:60) menyatakan ada beberapa hal yang harus diperhatikan dalam mengajarkan matematika di tingkat sekolah dasar yaitu siswa, guru, alat bantu dan proses belajar. 


\section{METODE}

Jenis penelitian ini termasuk jenis penelitian deskriptif kualitatif yang bertujuan untuk menggambarkan aktivitas siswa, hasil belajar dan respon siswa dalam menerapkan metode permainan bingo matematik pada materi operasi hitung pecahan. Penelitian ini dilaksanakan di SDN Pakis V Surabaya dengan subyek penelitian siswa kelas IV-C sebanyak 38 siswa. Penelitian ini menggunakan rancangan penelitian dengan desain "One Shot Case Study" yaitu penelitian yang dilakukan dengan memberikan perlakuan tertentu kapada subyek penelitian, dalam hal ini metode permainan pada materi operasi hitung pecahan kemudian dilanjutkan dengan pendeskripsian hasil pengamatan terhadap aktivitas siswa selama perlakuan, serta respon siswa dan hasil tes belajar siswa sesudah perlakuan tersebut.

Data yang diperlukan pada penelitian ini adalah data tentang aktivitas siswa selama proses pembelajaran berlangsung dan data hasil belajar matematika siswa kelas 4-C SDN Pakis V Surabaya pada materi pecahan semester genap tahun pelajaran 2015 - 2016. Data tentang aktivitas siswa dikumpulkan dengan menggunakan lembar pengamatan aktivitas siswa yang diisi oleh rekan yang membantu peneliti dalam pengamatan dengan memberi skor pada setiap indikator. Data respon siswa selama pembelajaran dikumpulkan dengan menggunakan angket yang diisi oleh siswa dengan peneliti menjelaskan terlebih dahulu cara pengerjaannya kepada siswa. Data tentang hasil belajar siswa setelah proses pembelajaran dikumpulkan dengan menggunakan tes hasil belajar yang dilakukan pada akhir pembelajaran. Data hasil belajar digunakan untuk menentukan ketuntasan hasil belajar matematika, keberhasilan penerapan metode permainan bingo matematik.

Dalam penelitian ini aktivitas siswa dikatakan aktif jika prosentase aktivitas siswa yang dikategorikan aktif lebih besar daripada aktivitas siswa yang dikategorikan pasif. Siswa memiliki respon positif dan berminat terhadap komponen pembelajaran jika besarnya presentase respon siswa yang menyatakan "ya" lebih besar dari $80 \%$ (dalam Rohmah, 2002: 41). Kesimpulan diperoleh berdasarkan persentase yang diperoleh guna mengetahui pendapat siswa tentang pembelajaran yang telah dilaksanakan. Setiap siswa dikatakan tuntas belajarnya (ketuntasan individu) jika proporsi jawaban benar siswa $\geq$ $65 \%$, dan suatu kelas dikatakan tuntas belajarnya (ketuntasan klasikal) jika dalam kelas tersebut terdapat $\geq 85 \%$ siswa yang telah tuntas belajarnya (Depdikbud dalam Trianto, 2010: 241). 


\section{HASIL DAN PEMBAHASAN}

Data yang diperoleh dalam penelitian ini akan dianalisis dan digunakan untuk menjawab pertanyaan penelitian. Dari hasil penelitian diperoleh informasi bahwa rata rata aktivitas belajar peserta didik yang menonjol adalah (1) Mendengarkan/ memperhatikan secara aktif sebesar $89,47 \%$. (2) Bertanya/ menjawab/ berdiskusi antara sesama teman atau antara siswa dengan guru sebesar $84,21 \%$. (3) Membaca/ memahami/ mengerjakan LKS sebesar 97,36\%. (4) Mempresentasikan hasil diskusi/ mengambil kesimpulan sebesar 52,63\%. (5) Melaksanakan tanggung jawab dalam kegiatan turnamen 39,47\%. (6) Perilaku yang tidak relevan dengan KBM sebesar 7,89\%. Aktivitas aktif peserta didik selama pembelajaran ditunjukkan dengan nomor aktifitas 1, 2, 4, dan 5 dengan rata - rata aktivitas aktif sebesar $66,44 \%$. Aktivitas pasif peserta didik selama pembelajaran ditunjukkan dengan nomor aktivitas 3 dan 6 sebesar 43,41\%. Dari kedua aktivitas tersebut didapat bahwa rata-rata aktivitas peserta didik aktif lebih besar dari ratarata aktifitas peserta didik pasif $(66,44 \%>52,62 \%)$, sehingga dikatakan aktivitas peserta didik dalam mengikuti pembelajaran dikategorikan aktif.

Data hasil angket respon siswa menunjukkan seberapa besar respon peserta didik terhadap pembelajaran dengan menggunakan metode permainan bingo matematik. Dari hasil penelitian diperoleh bahwa skor rata - rata hasil angket respon peserta didik terhadap pembelajaran dengan metode permainan bingo matematik sebesar 80,18\%, dengan demikian respon peserta didik terhadap pembelajaran dengan menggunakan metode permainan bingo matematik adalah positif dan peserta didik memiliki minat dalam mengikuti pembelajaran.

Dari hasil penelitian menunjukkan terdapat 37 siswa yang mengikuti tes hasil belajar, diperoleh siswa yang telah tuntas belajar secara individu dan siswa yang tidak tuntas secara individu. Sehingga presentase yang telah tuntas sebanyak 89,18\% sedangkan yang tidak tuntas sebanyak 10,82\% (33 peserta didik tuntas secara individual dari 37 keseluruhan kelas IV-C) dengan demikian tercapai ketuntasan belajar secara klasikal.

\section{KESIMPULAN DAN SARAN}

Berdasarkan hasil penelitian dan pembahasan yang telah diuraikan, maka dapat disimpulkan aktivitas peserta didik dalam mengikuti pembelajaran dengan menggunakan metode permainan bingo matematik dikategorikan aktif. Respon yang ditangkap oleh 
siswa positif dan memiliki minat dalam mengikuti pembelajaran, dengan perolehan nilai persentase sebesar $80,18 \%$. Hasil perolehan belajar siswa tuntas secara klasikal.

Peneliti memberikan saran bagi peneliti berikutnya atau guru agar menerapkan metode permainan dengan lebih efektif, yaitu:

1. Penyampaian tujuan permainan sebaiknya tidak disampaikan secara langsung oleh guru namun siswa dipancing untuk bertanya agar siswa lebih aktif dan meningkatkan rasa ingin tahu siswa.

2. Papan bingo dibuat lebih besar sehingga siswa yang duduk di belakang bisa melihat dengan jelas.

3. Pembuatan aturan-aturan permainan melibatkan siswa dan dibuat kesepakatan agar siswa merasa lebih dilibatkan dalam penentuan aturan sehingga lebih bertanggung jawab untuk mematuhinya.

4. Permainan dibuat sedemikian rupa agar siswa lebih bebas bergerak dan merasa semakin senang dalam menyelesaikan permainan.

5. Diskusi kelompok tidak terlalu dominan dalam permainan agar tidak banyak terjadi perselisihan pendapat antar siswa yang berujung pada pertengkaran.

\section{DAFTAR RUJUKAN}

Abu A. dan Joko T. P. (2005). Strategi Belajar-Mengajar. Bandung: Pustaka Setia.

Arikunto, S. (1996). Prosedur Penelitian Suatu Pendekatan Praktek. Jakarta: Rineka Cipta.

Depdiknas. (2005). Peraturan Pemerintah Republik Indonesia No. 19 th 2005 tentang Standar Nasional Pendidikan. Jakarta: Depdiknas.

Dinar, S. J. (2014). Penerapan Metode Permainan Bingo untuk Meningkatkan Motivasi Belajar Siswa dalam Pembelajaran Sejarah. Bandung: UPI Press.

Djamarah, S. B. dan Aswan Zain. (2002). Strategi Belajar Mengajar. Jakarta: Rineka Cipta.

DjamarahS. B.dan Zain. (2006). Strategi Belajar Mengajar. Jakarta: Rineka Cipta.

Gerlach, V.S. dan Ely, D. P. (1980). Teaching \& Media: A Systematic Approach. Second Edition. Englewood Cliffs, New Jersey: Prentice Hall, Inc.

Heruman. (2012). Model Pembelajaran Matematika di SD. Bandung: Rosdakarya.

Hudoyo, H. (1988). Strategi Belajar Mengajar Matematika. Jakarta : Depdikbud.

Hudojo.(2005). Pengembangan Kurikulum dan Pembelajaran Matematika. Malang: UM Press. 
Indaryanti. (2014). Pengembangan Modul Pembelajaran Individual dalam Mata Pelajaran Matematika, Jurnal Pendidikan Matematika, Volume 2, nomor 2, http://eprints.unsuri.ac.iddiakses pada tanggal 5 Mei 2016.

Rahayu, P. (2012). Implementasi dan Pengembangan Model Permainan Funtastic "Ganbatte dan Bingo Matematik" untuk Meningkatkan Ketrampilan Operasi Hitung Perkalian Siswa Kelas 3 SD. Bandumg: UPI Press.

Rohmah, D. Y. (2002). Pengaruh Sikap dan Gender terhadap Prestasi Belajar Bahasa Indonesia pada Siswa SMP Negeri Kelas VII. Yogyakarta: UNY Press.

Sadiman, A. (2002). Media Pembelajaran dan Proses Belajar Mengajar, Pengertian Pengembangan dan Pemanfaatannya, Jakarta: Raja Grafindo Persada.

Trianto.(2010). Mengembangkan Model Pembelajaran Tematik, Jakarta: PT Prestasi Pustaka. 